\title{
Molecular Detection of Bartonella spp. and Hematological Evaluation in Domestic Cats and Dogs from Bangkok, Thailand
}

\author{
Phirabhat Saengsawang ${ }^{1,2,3} \mathbb{D}$, Gunn Kaewmongkol ${ }^{4}$ and Tawin Inpankaew $1,2,5, * \mathbb{D}$ \\ 1 Center for Agricultural Biotechnology, Kamphaeng Saen Campus, Kasetsart University, \\ Nakhon Pathom 73140, Thailand; phirabhat.s@gmail.com \\ 2 Center of Excellence on Agricultural Biotechnology (AG-BIO/PERDO-CHE), Bangkok 10900, Thailand \\ 3 Akkhraratchakumari Veterinary College, Walailak University, Nakhon Si Thammarat 80161, Thailand \\ 4 Department of Companion Animal Clinical Sciences, Faculty of Veterinary Medicine, Kasetsart University, \\ Bangkok 10900, Thailand; gunn_kaew@yahoo.com \\ 5 Department of Parasitology, Faculty of Veterinary Medicine, Kasetsart University, Bangkok 10900, Thailand \\ * Correspondence: fvettwi@ku.ac.th or tawin.i@ku.th
}

check for

updates

Citation: Saengsawang, P.; Kaewmongkol, G.; Inpankaew, T.

Molecular Detection of Bartonella spp. and Hematological Evaluation in

Domestic Cats and Dogs from Bangkok, Thailand. Pathogens 2021, 10, 503. https://doi.org/ 10.3390 / pathogens 10050503

Academic Editor: Edward

B. Breitschwerdt

Received: 24 March 2021

Accepted: 20 April 2021

Published: 22 April 2021

Publisher's Note: MDPI stays neutral with regard to jurisdictional claims in published maps and institutional affiliations.

Copyright: (c) 2021 by the authors. Licensee MDPI, Basel, Switzerland. This article is an open access article distributed under the terms and conditions of the Creative Commons Attribution (CC BY) license (https:// creativecommons.org/licenses/by/ $4.0 /)$.

\begin{abstract}
Background: Bartonella spp. are Gram-negative, facultative, intracellular bacteria transmitted by hematophagous insects. Several species cause zoonotic diseases such as cat-scratch disease. Bartonella henselae and Bartonella clarridgeiae are the main species found in Thailand, however, there have been few studies on Bartonella spp. In addition, the hematological evaluation of Bartonella-infected animals is limited in Thailand. The aims of this study were prevalence investigation and hematological evaluation of Bartonella-infected dogs and cats residing in Bangkok, Thailand. (2) Methods: In total, 295 dogs and 513 cats were molecularly evaluated to detect Bartonella spp. using PCR with primers targeting the partial glt $A, r p o B, f t s Z, r i b C$, and groEL genes. In total, 651 domestic animals were evaluated for hematological parameters compared between Bartonella-positive and Bartonella-negative animals. (3) Results: Overall, the prevalence of Bartonella spp. was $1.61 \%$ which was found only in free-ranging cats (2.83\%). Bartonella henselae and B. clarridgeiae were confirmed from a concatenated phylogenetic tree of partial glt $A$ and ribC genes, with $100 \%$ bootstrapping replication. For other housekeeping gene sequences, mixed infection was expected from the amplicons of $r p o B$, ftsZ, and groEL. Importantly, the mean corpuscular volume (MCV) was significantly increased in Bartonella-positive cats. (4) Conclusions: We suggest that B. henselae and B. clarridgeiae are important species and are still circulating in domestic animals, especially cats. The evaluation of blood parameters, especially a raised MCV, should be of concern in Bartonella infection in asymptomatic cats. Additionally, the knowledge of how to prevent Bartonella-related diseases should be promoted with people in at-risk situations.
\end{abstract}

Keywords: Bartonella; dog; cat; phylogenetic; hematology; Thailand

\section{Introduction}

Bartonella spp. are Gram-negative, facultative, fastidious intracellular bacteria causing various pathological changes and bacteremia in their natural and accidental hosts. Several bloodsucking arthropods have been confirmed as vectors transmitting these pathogens including cat fleas (Ctenocephalides felis) [1], human fleas (Pulex irritans) [2], human lice (Pediculus humanus) [3], and sandflies (Luztomyia verrucarum) [4]. Additionally, some tick species are suggested as possible vectors of Bartonella spp. such as the brown dog tick (Rhipicephalus sanguineus) [5] and the Ixodid tick (Ixodes spp. [6] and Dermacentor spp. [7]). Up to the present, a number of new species of Bartonella and candidatus Bartonella have been described and more than 35 species have revealed their whole genome.

Human bartonelloses are caused by B. henselae (cat-scratch disease), B. bacilliformis (Carrion's disease and verruga peruana), and B. quintana (trench fever) [8]. Humans play a role as accidental hosts being infected by Bartonella spp. from various animal hosts, both 
companion and wild animals [9]. Bartonellosis mainly affects immunocompromised patients, however, only regional lymphadenopathy occurs in immunocompetent people [10]. At least 13 species are considered as zoonotic agents and the most zoonotic-prevalent species is $B$. henselae, which can cause an asymptomatic infection among the hosts, such as carnivores, rodents, and ruminants [10-12].

Dogs and cats are defined as family members sharing household environments with humans in both urban and rural areas, and they are considered as a source of zoonotic infection, especially of bartonellosis [13]. In addition, dogs and cats are major mammals that can act as reservoirs of Bartonella spp. [14] and are defined as the main animals transmitting these pathogens to humans. Importantly, cats have been described as a primary reservoir animal of human bartonellosis [15], but dogs are defined as accidental hosts of these pathogens due to a lack of clear evidence [16]. The clinical signs in cats are mostly mild compared with dogs, however, some hematological parameters of both animals are changed [14]. The evaluation of blood parameters in Bartonella-infected animals, particularly cats and dogs, is still unclear. Several studies in other countries have evaluated the blood parameters in Bartonella-infected animals. Importantly, blood parameters are frequently used to diagnose and monitor animal health. Even if domestic cats and dogs are popular in Thailand, there has been little hematological study comparing uninfected- and infected-Bartonella animals.

In Thailand, dogs and cats that are both free-ranging and owned cohabit human communities. Bangkok is a province where the density of temples and household are considered high. Free-ranging animals were frequently found in temples which were a place for cultural activities and festivals, and owned animals were also found in the household. Significantly, the pattern of familiarity between humans and their belonging animals might induce zoonotic infection, particularly bartonellosis. The main proven modes of transmission in the human are animal scratch or bite with Bartonella-contaminated vector feces, and blood-sucking arthropod bite [14]. However, there have been few studies reporting evidence of Bartonella in domestic animals in Thailand. The objectives of this study were to investigate the prevalence of Bartonella spp. in domestic dogs and cats and to evaluate the hematological parameters of Bartonella-infected dogs and cats in Bangkok, Thailand.

\section{Results}

\subsection{Animal Demographic Characteristics}

In total, 808 blood samples were collected from domestic cats $(n=513)$ and dogs ( $n=295$ ) residing in Bangkok, Thailand, consisting of 634 free-ranging (from temples) and 174 owned animals (from KUVTH). The ratio of males to females in the animals was 1.26:1 in the owned and 0.83:1 in the free-ranging animals. The mean \pm standard deviation age of studied animals was $3.03 \pm 2.01$ years in the free-ranging animals $(2.83 \pm 1.71$ years in cats and $3.29 \pm 2.33$ years in dogs), and in the owned animals was $3.47 \pm 1.75$ years $(3.22 \pm 1.71$ years in cats and $3.58 \pm 1.77$ years in dogs). The numbers for related factors (gender, living location, breed, animal species, age group, and ectoparasite infestation) are presented in Table 1.

\subsection{Prevalence of Bartonella spp.}

The overall prevalence of Bartonella spp. in the domestic dogs and cats was $1.61 \%$ $(13 / 808)$. Only domestic cats presented Bartonella DNA in extracted blood samples, however, there was an evidence only in free-ranging cats (2.83\%) residing in temples (Table 2). Notably, there was no Bartonella-positive blood in domestic dogs (both free-ranging and owned animals) in the current study. Bartonella spp. were detected in animals residing in $10 / 54(18.52 \%)$ temple clusters that were located in three zones of Bangkok (Figure 1). The positive proportions in the separate zones were in the range of $10.53-23.08 \%(6 / 26$ clusters in the inner zone, 2/19 clusters in the intermediate zone, 2/9 clusters in the outer zone) and there were no significant differences between zones $(p=0.35)$. Additionally, there 
were no significant differences for gender $(p=0.34)$, age group $(p=0.51)$, and ectoparasite infestation $(p=0.22)$ in the examined animals.

Table 1. Number of related factors of examined animals in this study.

\begin{tabular}{|c|c|c|c|c|}
\hline \multirow{2}{*}{ Factors } & \multicolumn{2}{|c|}{ Free Ranging } & \multicolumn{2}{|c|}{ Owned } \\
\hline & Dog & Cat & Dog & Cat \\
\hline \multicolumn{5}{|l|}{ Gender ${ }^{1}$} \\
\hline Male & 82 & 206 & 64 & 32 \\
\hline $\begin{array}{l}\text { Female } \\
\text { Studied zone }\end{array}$ & 92 & 254 & 57 & 19 \\
\hline Inner & 65 & 223 & - & - \\
\hline Intermediate & 48 & 169 & - & - \\
\hline \multicolumn{5}{|l|}{ Breed } \\
\hline Purebred & 0 & 0 & 90 & 6 \\
\hline $\begin{array}{l}\text { Crossbred } \\
\text { Age group }\end{array}$ & 174 & 460 & 31 & 47 \\
\hline$<1$ year & 42 & 66 & 0 & 0 \\
\hline $1-5$ years & 100 & 362 & 97 & 47 \\
\hline $\begin{array}{l}>5 \text { years } \\
\text { Ectoparasites }\end{array}$ & 32 & 32 & 24 & 6 \\
\hline Yes & 16 & 223 & 0 & 0 \\
\hline - Flea & 1 & 223 & 0 & 0 \\
\hline - Tick & 9 & 0 & 0 & 0 \\
\hline - Flea and tick & 6 & 0 & 0 & 0 \\
\hline No & 158 & 237 & 121 & 53 \\
\hline Total & 174 & 460 & 121 & 53 \\
\hline
\end{tabular}

${ }^{1}$ Gender of two owned cats were unrecorded.

\subsection{Phylogenetic Analysis}

The BLAST results of all gltA-positive amplicons showed a similar direction with matched species of $r i b C$ gene results. However, $r p o B, f t s Z$, and groEL revealed different species (Table 3). In addition, the amplicons of five samples (38.46\%) showed two species of Bartonella. Amplicons of $g l t A$ and ribC matched with two species of Bartonella consisting of $B$. henselae (\%identity $=97.01-100 \%$ of $g l t A$ and $86.62-100 \%$ of ribC) and B. clarridgeiae (\%identity $=94.59-100 \%$ of glt $A$ and $99.54-100 \%$ of ribC). Additionally, the similarity was up to $100 \%$ for $r p o B, f t s Z$, and groEL in all sequences, and details of sequencing data are revealed in Supplementary Table S1. The concatenated phylogenetic tree based on the maximum likelihood (ML) method with the general time reversible (GTR) model and a Gamma distribution based on partial glt $A$ and $r i b C$ sequences showed two lineages of Bartonella that were identical to B. henselae and B. clarridgeiae, with $100 \%$ bootstrapping replication (Figure 2).

Table 2. Number and prevalence of Bartonella spp. with 95\% confidence interval of studied dogs and cats in this study.

\begin{tabular}{cccc}
\hline Host & No. Positive/No. Tested & \% Bartonella Positive & 95\% Confidence Interval \\
\hline Free ranging & $0 / 174$ & $0 \%$ & - \\
Owned & $0 / 121$ & $0 \%$ & - \\
Total dogs & $0 / 295$ & $0 \%$ & - \\
Free ranging & $13 / 460$ & $2.83 \%$ & $1.51-4.78 \%$ \\
Owned & $0 / 53$ & $0 \%$ & - \\
Total cats & $13 / 513$ & $2.53 \%$ & $1.36-4.29 \%$ \\
\hline
\end{tabular}




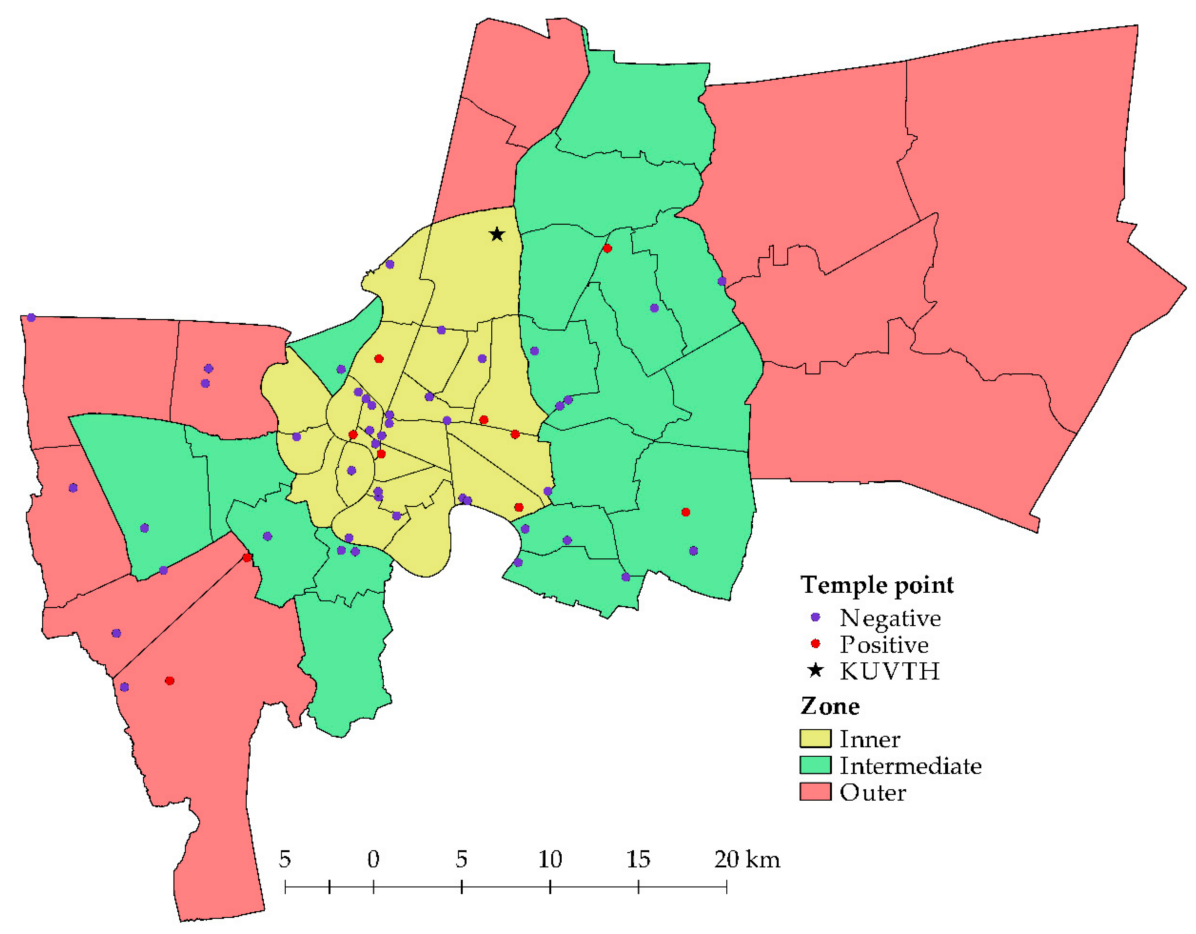

Figure 1. Map of Bangkok and studied temples; each polygon indicates a district boundary; each circular symbol indicates a temple location; and the asterisk symbol indicates the location of KUVTH.

Table 3. Accession number of each sequence submitted to the GenBank database, BLAST results, and identity percentage.

\begin{tabular}{|c|c|c|c|c|c|c|c|c|c|c|}
\hline \multirow{2}{*}{ ID } & \multicolumn{2}{|c|}{ gltA } & \multicolumn{2}{|c|}{ rpoB } & \multicolumn{2}{|c|}{$f t s Z$} & \multicolumn{2}{|c|}{ groEL } & \multicolumn{2}{|c|}{$r i b C$} \\
\hline & ACNO & BLAST & ACNO & BLAST & ACNO & BLAST & ACNO & BLAST & ACNO & BLAST \\
\hline \multirow[t]{2}{*}{02901} & MW575345 & $\mathrm{BC}$ & MW575391 & $\mathrm{Bh}$ & MW575370 & 02901 & MW575345 & $\mathrm{Bc}$ & MW575391 & $\mathrm{Bh}$ \\
\hline & \multicolumn{2}{|c|}{ [94.59-100\%] } & \multicolumn{2}{|c|}{ [99.41-100\%] } & \multicolumn{2}{|c|}{ [99.23-100\%] } & \multicolumn{2}{|c|}{ [98.94-100\%] } & \multicolumn{2}{|c|}{ [99.54-100\%] } \\
\hline \multirow[t]{2}{*}{03302} & MW575346 & $\mathrm{Bc}$ & MW575386 & $\mathrm{Bh}$ & MW575371 & 03302 & MW575346 & $\mathrm{Bc}$ & MW575386 & $\mathrm{Bh}$ \\
\hline & \multicolumn{2}{|c|}{ [94.59-100\%] } & \multicolumn{2}{|c|}{ [99.41-100\%] } & \multicolumn{2}{|c|}{ [99.23-100\%] } & \multicolumn{2}{|c|}{ [98.94-100\%] } & \multicolumn{2}{|c|}{ [99.54-100\%] } \\
\hline \multirow[t]{2}{*}{04102} & MW575347 & $\mathrm{Bc}$ & $(-)$ & & MW575372 & 04102 & MW575347 & $\mathrm{Bc}$ & $(-)$ & \\
\hline & \multicolumn{2}{|c|}{ [94.59-100\%] } & & & \multicolumn{2}{|c|}{ [99.23-100\%] } & & & \multicolumn{2}{|c|}{ [94.59-100\%] } \\
\hline \multirow[t]{2}{*}{05909} & MW575348 & $\mathrm{Bc}$ & MW575392 & $\mathrm{Bh}$ & MW575373 & 05909 & MW575348 & $\mathrm{Bc}$ & MW575392 & $\mathrm{Bh}$ \\
\hline & \multicolumn{2}{|c|}{ [94.59-100\%] } & \multicolumn{2}{|c|}{ [99.41-100\%] } & \multicolumn{2}{|c|}{ [99.23-100\%] } & \multicolumn{2}{|c|}{ [98.94-100\%] } & \multicolumn{2}{|c|}{ [99.54-100\%] } \\
\hline \multirow[t]{2}{*}{06806} & MW575349 & $\mathrm{Bc}$ & MW575390 & $\mathrm{Bh}$ & MW575379 & 06806 & MW575349 & $\mathrm{Bc}$ & MW575390 & $\mathrm{Bh}$ \\
\hline & \multicolumn{2}{|c|}{ [94.59-100\%] } & \multicolumn{2}{|c|}{ [98.95-100\%] } & \multicolumn{2}{|c|}{ [99.39-100\%] } & \multicolumn{2}{|c|}{ [98.94-100\%] } & [99.54-1 & $00 \%]$ \\
\hline 07406 & MW575350 & $\mathrm{BC}$ & $(-)$ & & $(-)$ & 07406 & MW575350 & $\mathrm{BC}$ & $(-)$ & \\
\hline & [94.59-1 & 00\%] & & & & & & $\begin{array}{c}{[94.59-} \\
100 \%]\end{array}$ & & \\
\hline 08303 & MW575351 & $\mathrm{Bc}$ & $(-)$ & & $(-)$ & 08303 & MW575351 & $\mathrm{Bc}$ & $(-)$ & \\
\hline & [94.59-1 & $00 \%]$ & & & & & & & [94.59-1 & $00 \%]$ \\
\hline 08501 & MW575353 & $\mathrm{Bh}$ & MW575387 & $\mathrm{Bh}$ & MW575374 & 08501 & MW575353 & $\mathrm{Bh}$ & MW575387 & $\mathrm{Bh}$ \\
\hline & [97.01-1 & $00 \%]$ & {$[99.41-]$} & $00 \%]$ & [99.23-1 & $00 \%]$ & & & & \\
\hline 08508 & MW575352 & $\mathrm{Bc}$ & $(-)$ & & $(-)$ & 08508 & MW575352 & $\mathrm{Bc}$ & $(-)$ & \\
\hline & [94.59-1 & $00 \%]$ & & & & & & & [94.59-1 & $00 \%]$ \\
\hline 09304 & MW575354 & $\mathrm{Bh}$ & MW575388 & $\mathrm{Bh}$ & MW575375 & 09304 & MW575354 & $\mathrm{Bh}$ & MW575388 & $\mathrm{Bh}$ \\
\hline & [97.01-1 & $00 \%]$ & {$[99.41-]$} & $00 \%]$ & [99.23-1 & $00 \%]$ & & & & \\
\hline
\end{tabular}


Table 3. Cont.

\begin{tabular}{|c|c|c|c|c|c|c|c|c|c|c|}
\hline \multirow{2}{*}{ ID } & \multicolumn{2}{|c|}{ gltA } & \multicolumn{2}{|c|}{ rpoB } & \multicolumn{2}{|c|}{$f t s Z$} & \multicolumn{2}{|c|}{ groEL } & \multicolumn{2}{|c|}{ ribC } \\
\hline & ACNO & BLAST & ACNO & BLAST & ACNO & BLAST & ACNO & BLAST & ACNO & BLAST \\
\hline \multirow[t]{2}{*}{09306} & MW575344 & $\mathrm{Bh}$ & MW575393 & $\mathrm{Bh}$ & MW575376 & 09306 & MW575344 & $\mathrm{Bh}$ & MW575393 & $\mathrm{Bh}$ \\
\hline & \multicolumn{2}{|c|}{ [97.01-100\%] } & \multicolumn{2}{|c|}{ [99.41-100\%] } & \multicolumn{2}{|c|}{ [99.23-100\%] } & & & & \\
\hline \multirow[t]{2}{*}{09701} & MW575355 & $\mathrm{Bh}$ & MW575389 & $\mathrm{Bh}$ & MW575377 & 09701 & MW575355 & $\mathrm{Bh}$ & MW575389 & $\mathrm{Bh}$ \\
\hline & \multicolumn{2}{|c|}{ [97.01-100\%] } & \multicolumn{2}{|c|}{ [99.41-100\%] } & \multicolumn{2}{|c|}{ [99.23-100\%] } & & & & \\
\hline \multirow[t]{2}{*}{09707} & MW575356 & $\mathrm{Bh}$ & MW575394 & $\mathrm{Bh}$ & MW575378 & 09707 & MW575356 & $\mathrm{Bh}$ & MW575394 & $\mathrm{Bh}$ \\
\hline & \multicolumn{2}{|c|}{ [97.01-100\%] } & \multicolumn{2}{|c|}{ [99.41-100\%] } & \multicolumn{2}{|c|}{ [99.23-100\%] } & & & & \\
\hline
\end{tabular}

ACNO: Accession number; Bc: Bartonella clarridgeiae; Bh: Bartonella henselae; (-): Amplicon absence; [ ]: \% identity.

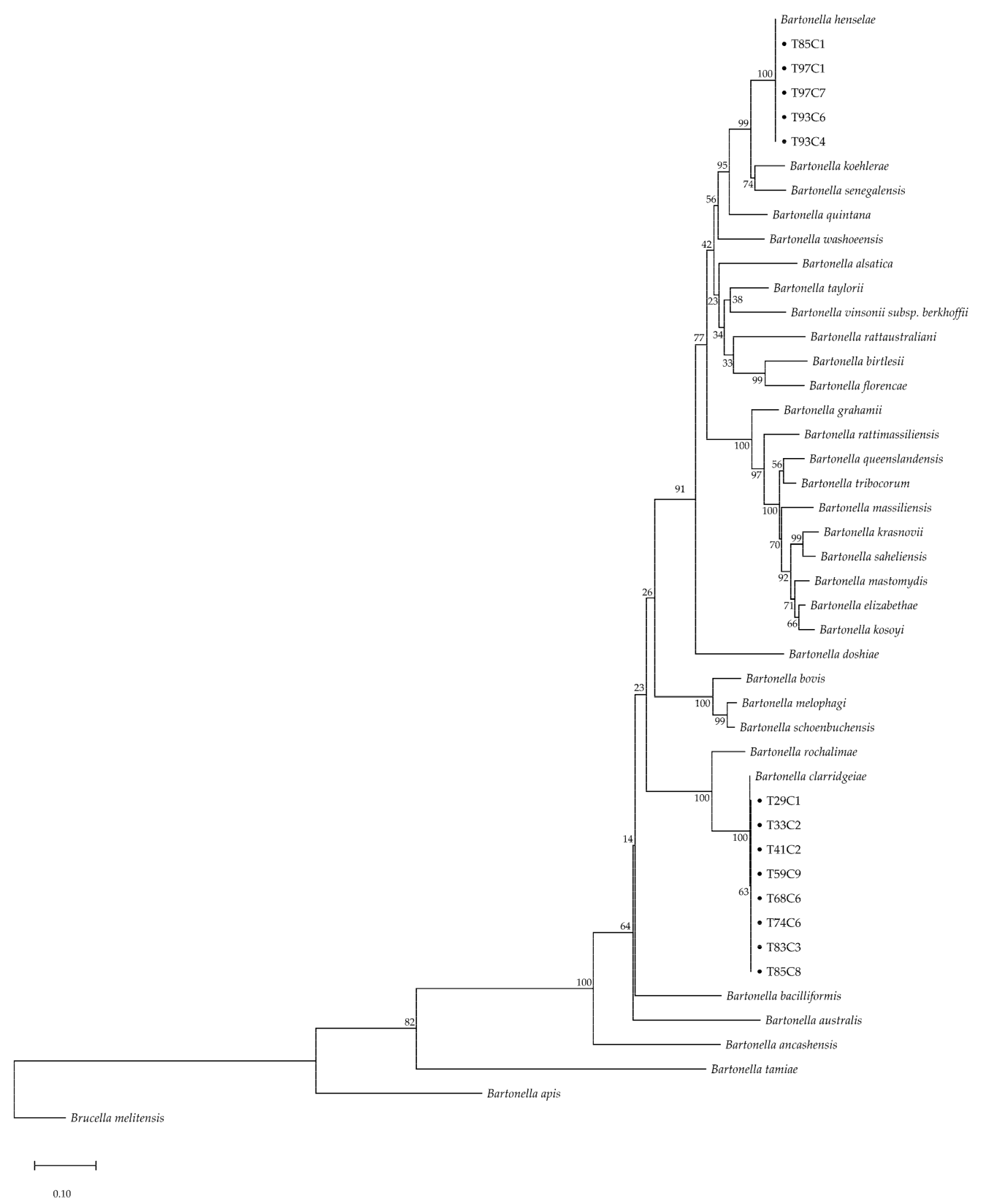

Figure 2. Phylogenetic tree of concatenated sequences ( $g l t A$ and ribC) of Bartonella-positive cats (maximum likelihood tree with GTR + G model with 500 bootstrapping replications); Brucella melitensis is provided as an outgroup; and dots indicate positive samples from the current study. 


\subsection{Hematological Comparison}

In total, 650 examined animals $(80.45 \%)$ were evaluated for blood parameters. The hematological results of the examined animal population were presented in Table 4 . The hematological evaluation was carried out in Bartonella-positive animal groups and so there was only a comparison made for free-ranging cats. The hematological comparison between positive and negative Bartonella spp. of free-ranging cats is shown in Figure 3. There were no significant differences in blood parameters between Bartonella-positive and Bartonellanegative animals, except for MCV of erythrocytes. There was a significantly raised value for MCV (48.65 $\pm 4.78 \mathrm{fL}$ for non-infected and $51.02 \pm 3.60 \mathrm{fL}$ for infected free-ranging cats) in Bartonella-infected free-ranging cats $(p<0.05)$. Moreover, more than $36 \%$ of positive cats had low PCV, HGB, and MCHC. The reference of blood parameters was included in Supplementary Table S2.

Table 4. Number of examined dogs and cats classified by hematological values *.

\begin{tabular}{|c|c|c|c|c|c|c|}
\hline \multirow{2}{*}{ Parameter } & \multicolumn{3}{|c|}{ Owned Dogs $(n=122)$} & \multicolumn{3}{|c|}{ Owned Cats $(n=52)$} \\
\hline & Low & Normal & High & Low & Normal & High \\
\hline PCV & $\begin{array}{c}1(0) \\
{[3310]}\end{array}$ & $\begin{array}{c}121(0) \\
4723+3711\end{array}$ & - & $\begin{array}{c}2(0) \\
{[32.05+375]}\end{array}$ & $\begin{array}{c}36(0) \\
{[41.33+229]}\end{array}$ & $\begin{array}{c}14(0) \\
733+1\end{array}$ \\
\hline RBC & {$[33.1$} & {$\left[\begin{array}{l}{[4 / .2} \\
113(0)\end{array}\right.$} & $9(0)$ & {$[32.05]$} & $\begin{array}{r}{\left[\begin{array}{l}41.03 \\
49(0)\end{array}\right.} \\
49(0)\end{array}$ & $\begin{array}{l}3.33 \pm 1 \\
3(0)\end{array}$ \\
\hline$\left(\times 10^{6} / \mu \mathrm{L}\right)$ & - & {$[6.84 \pm 0.55]$} & {$[8.17 \pm 0.40]$} & - & {$[8.71 \pm 0.72]$} & {$[10.48 \pm 0.11]$} \\
\hline HGB & & $117(0)$ & $5(0)$ & $1(0)$ & $45(0)$ & $6(0)$ \\
\hline$(\mathrm{g} / \mathrm{dL})$ & $a^{-}$ & {$[16.28 \pm 1.14]$} & {$[19.26 \pm 0.23]$} & {$[9.14]$} & {$[13.73 \pm 0.90]$} & {$[16.03 \pm 0.36]$} \\
\hline $\mathrm{MCV}$ & $24(0)$ & $98(0)$ & 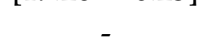 & - & $51(0)$ & $1(0)$ \\
\hline (fL) & {$[62.83 \pm 2.44]$} & {$[69.33 \pm 1.84]$} & 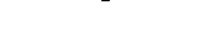 & - & {$[47.81 \pm 3.20]$} & [18.37] \\
\hline $\mathrm{MCH}$ & $2(0)$ & $118(0)$ & $2(0)$ & - & $48(0)$ & $4(0)$ \\
\hline$(\mathrm{pg})$ & {$[20.99 \pm 0.00]$} & {$[23.70 \pm 1.13]$} & {$[26.69 \pm 0.41]$} & - & {$[15.64 \pm 0.82]$} & {$[17.59 \pm 0.52]$} \\
\hline $\mathrm{MCHC}$ & - & $112(0)$ & $10(0)$ & - & $48(0)$ & $4(0)$ \\
\hline$(\mathrm{g} / \mathrm{dL})$ & 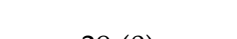 & {$[34.68 \pm 0.92]$} & {$[37.15 \pm 0.91]$} & & {$[32.64 \pm 0.93]$} & {$[36.71 \pm 0.21]$} \\
\hline PLT & $39(0)$ & $83(0)$ & 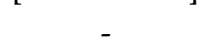 & $16(0)$ & $36(0)$ & $-1-2 c^{2}$ \\
\hline$\left(\times 10^{3} / \mu \mathrm{L}\right)$ & {$[187.10 \pm 29.76]$} & {$[267.41 \pm 47.82]$} & 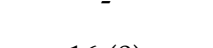 & {$[221.32 \pm 51.54]$} & [361.11 & 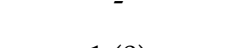 \\
\hline WBC & 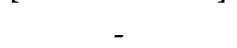 & $106(0)$ & $16(0)$ & $\mathbf{2}$ & $51(0)$ & $1(0)$ \\
\hline$\left(\times 10^{3} / \mu \mathrm{L}\right)$ & 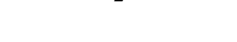 & {$[10.34$} & {$[15.14 \pm 0.72]$} & & {$[10.88 \pm 3.34]$} & [19.80] \\
\hline NEU & $11(0)$ & $105(0)$ & $6(0)$ & $2(0)$ & $26(0)$ & $24(0)$ \\
\hline LYM & $\begin{array}{c}{[54.27 \pm 4.38]} \\
6(0)\end{array}$ & $\begin{array}{r}{[72.20 \pm 6} \\
78(0)\end{array}$ & $\begin{array}{c}{[89.00 \pm 2.53]} \\
38(0)\end{array}$ & $\begin{array}{c}{[37.85 \pm 4.03]} \\
26(0)\end{array}$ & $18(0)$ & $\begin{array}{c}{[75.58 \pm 8.53]} \\
9(0)\end{array}$ \\
\hline$(\%)$ & {$[4.67 \pm 1.97]$} & {$[15.96$} & {$[29.18 \pm 5.65]$} & {$[17.42 \pm 6.10]$} & {$[30.65$} & {$[42.46 \pm 5.20]$} \\
\hline $\begin{array}{c}\text { EOS } \\
(\%)\end{array}$ & - & $\begin{array}{c}113(0) \\
{[4.18+2.52]}\end{array}$ & $\begin{array}{c}9(0) \\
{[12.43+3.51]}\end{array}$ & - & $\begin{array}{c}20(0) \\
{[2.34+1.42]}\end{array}$ & $\begin{array}{c}32(0) \\
{[7.29+2.57]}\end{array}$ \\
\hline MON & $\begin{array}{c}35(0) \\
\end{array}$ & $86(0)$ & $1(0)$ & - & {$[2.34 \pm 1.42]$} & $21(0)$ \\
\hline $\begin{array}{l}(\%) \\
\text { BAS }\end{array}$ & $31 \pm$ & $\begin{array}{r}{[5.21 \pm} \\
122(\end{array}$ & [11. & & $1.34]$ & $\pm 1.59]$ \\
\hline$(\%)$ & & {$[0.04 \pm 0.03]$} & & - & {$[0.11 \pm 0.10]$} & \\
\hline \multirow{2}{*}{ Parameter } & \multicolumn{3}{|c|}{ Free-Ranging Dogs $(n=133)$} & \multicolumn{3}{|c|}{ Cats $(n=343) * *$} \\
\hline & Low & Normal & High & Low & Norm & High \\
\hline PCV & $47(0)$ & $86(0)$ & & $147(4$ & 167 & 29( \\
\hline$(\%)$ & {$[29.09 \pm 5.13]$} & {$[43.68 \pm 4.89]$} & & {$[30.30 \pm 4.04]$} & {$[39.14 \pm 2.64]$} & {$[47.31 \pm 2.01]$} \\
\hline RBC & $55(0)$ & $74(0)$ & $4(0)$ & $16(2)$ & $318(9)$ & $9(0)$ \\
\hline$\left(\times 10^{6} / \mu \mathrm{L}\right)$ & {$[3.96 \pm 0.77]$} & {$[6.14 \pm 0.76]$} & {$[8.29 \pm 0.37$} & {$[4.18 \pm 0.81]$} & {$[7.53 \pm 1.11]$} & {$[10.49 \pm 0.54]$} \\
\hline HGB & $70(0)$ & $60(0)$ & $3(0)$ & $69(4)$ & $271(7)$ & $3(0)$ \\
\hline$(g / d L)$ & {$[9.26 \pm 1.95]$} & {$[14.11 \pm 1.51]$} & {$[19.30 \pm 0.35]$} & {$[8.45 \pm 1.19]$} & {$[12.12 \pm 1.39]$} & {$[16.50 \pm 0.78]$} \\
\hline MCV & $14(0)$ & $83(0)$ & $36(0)$ & $2(0)$ & $308(9)$ & $33(2)$ \\
\hline$(\mathrm{fL})$ & {$[60.79 \pm$} & {$[72.08 \pm 2.8$} & {$[82.62 \pm 4$} & {$[35.35 \pm 0$} & {$[47.80$} & {$[58.15 \pm 3.95]$} \\
\hline $\mathrm{MCH}$ & $27(0)$ & $105(0)$ & $1(0)$ & $4(0)$ & $317(10)$ & $22(1)$ \\
\hline (pg) & {$[19.57 \pm 1.53]$} & {$[22.62 \pm 1.12]$} & [30.50] & {$[12.33 \pm 0.49]$} & {$[15.27 \pm 0.87]$} & {$[17.78 \pm 1.06]$} \\
\hline MCHC & $112(0)$ & $20(0)$ & $1(0)$ & $72(5)$ & $264(6)$ & $7(0)$ \\
\hline$(\mathrm{g} / \mathrm{dL})$ & {$[29.32 \pm 1.74]$} & {$[33.49 \pm 1.00]$} & [36.50] & {$[28.84 \pm 0.81]$} & {$[32.37 \pm 1.43]$} & {$[36.83 \pm 0.64]$} \\
\hline PLT & $112(0)$ & $21(0)$ & - & $82(3)$ & $256(8)$ & $5(0)$ \\
\hline$\left(\times 10^{3} / \mu \mathrm{L}\right)$ & {$[101.36 \pm 46.74]$} & {$[312.10 \pm 93.05]$} & & {$[230.82 \pm 56.01]$} & {$[461.95 \pm 116.42]$} & {$[870.00 \pm 53.46]$} \\
\hline WBC & $4(0)$ & $69(0)$ & $60(0)$ & $3(1)$ & $210(8)$ & $130(2)$ \\
\hline$\left(\times 10^{3} / \mu \mathrm{L}\right)$ & {$[4.01 \pm 0.89]$} & {$[10.40 \pm 2.53]$} & {$[19.49 \pm 4.63]$} & {$[5.32 \pm 0.16]$} & {$[14.83 \pm 2.94]$} & {$[26.57 \pm 7.67]$} \\
\hline NEU & $69(0)$ & $61(0)$ & $3(0)$ & $60(2)$ & $184(5)$ & 99 (4) \\
\hline$(\%)$ & {$[46.71 \pm 8.73]$} & {$[66.85 \pm 6.24]$} & {$[87.17 \pm 2.6$} & {$[37.47 \pm 6.36]$} & {$[54.84 \pm 5.34]$} & {$[70.61 \pm 5.78]$} \\
\hline
\end{tabular}


Table 4. Cont.

\begin{tabular}{|c|c|c|c|c|c|c|}
\hline \multirow{2}{*}{ Parameter } & \multicolumn{3}{|c|}{ Free-Ranging Dogs $(n=133)$} & \multicolumn{3}{|c|}{ Cats $(n=343) * *$} \\
\hline & Low & Normal & High & Low & Normal & High \\
\hline $\begin{array}{c}\text { LYM } \\
(\%)\end{array}$ & $\begin{array}{c}4(0) \\
{[5.33 \pm 1.77]}\end{array}$ & $\begin{array}{c}40(0) \\
{[16.13 \pm 3.41]}\end{array}$ & $\begin{array}{c}89(0) \\
{[35.77 \pm 12.15]}\end{array}$ & $\begin{array}{c}116(3) \\
{[20.36 \pm 4.82]}\end{array}$ & $\begin{array}{c}100(5) \\
{[30.95 \pm 2.69]}\end{array}$ & $\begin{array}{c}127(3) \\
{[47.40 \pm 24.71]}\end{array}$ \\
\hline EOS & {$[0.001$} & $86(0)$ & $47(0)$ & ] & $74(3)$ & $269(8)$ \\
\hline$(\%)$ & - & {$[4.87 \pm 2.34]$} & {$[13.97 \pm 4.13]$} & - & {$[2.48 \pm 1.40]$} & {$[9.10 \pm 4.30]$} \\
\hline MON & $8(0)$ & $110(0)$ & $15(0)$ & - & $306(9)$ & $37(2)$ \\
\hline$(\%)$ & {$[0.21 \pm 0.20]$} & {$[5.57 \pm 2.22]$} & {$[11.17 \pm 1.15]$} & & {$[2.47 \pm 1.29]$} & {$[6.61 \pm 2.08]$} \\
\hline BAS & 0 & $133(0)$ & 0 & - & 343 (11) & _- \\
\hline$(\%)$ & - & {$[0.22 \pm 0.18]$} & - & - & {$[0.12 \pm 0.10]$} & - \\
\hline
\end{tabular}

${ }^{*}$ Numbers in ( ) are the Bartonella-positive sample in each hematological class; [ ] is the average value of each hematological value. ${ }^{* *}$ There were 11 of 13 Bartonella infected free-ranging cats that obtained blood parameters.
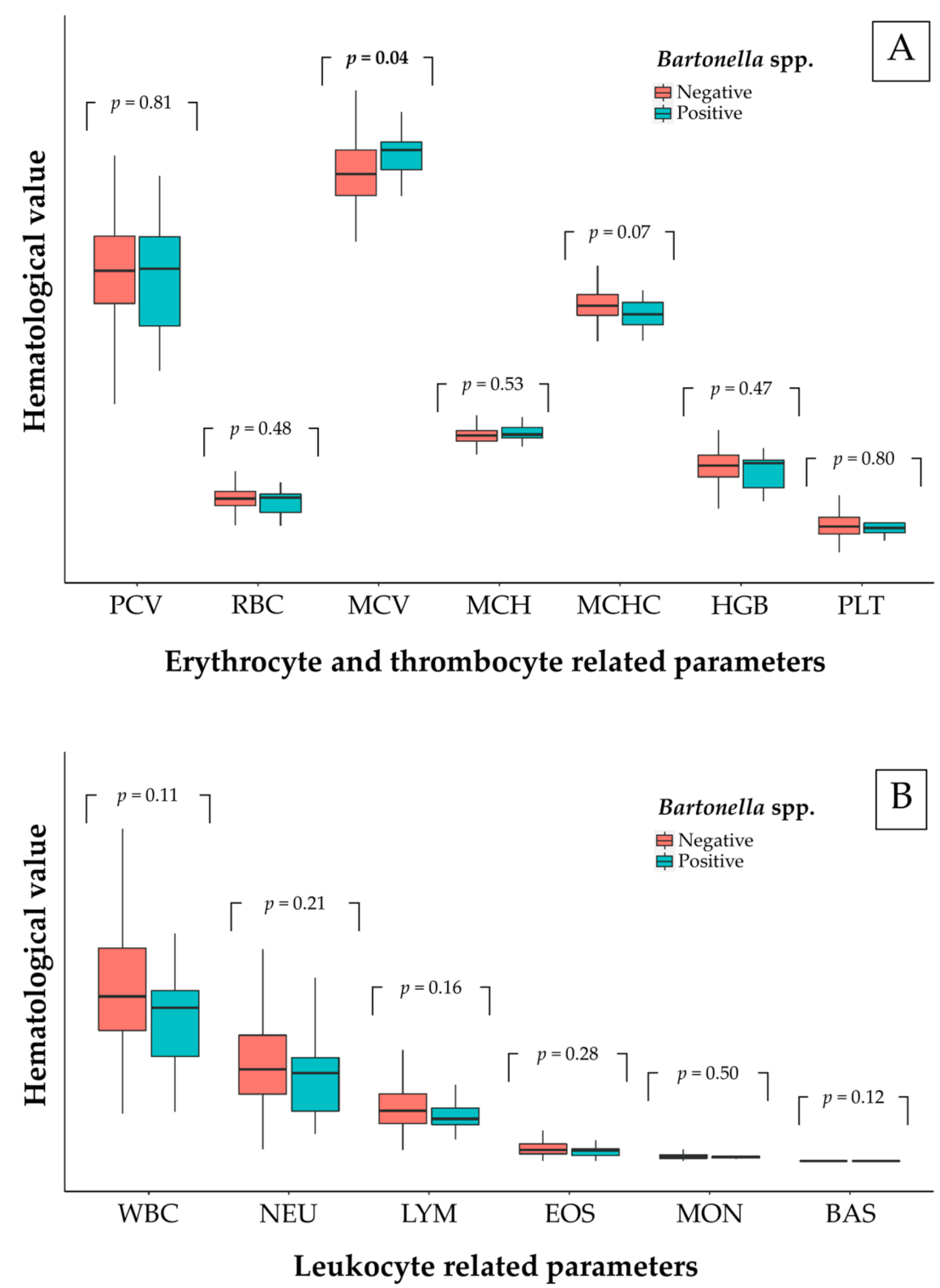

Figure 3. Box plot of each related hematological parameter in free-ranging cats; (A) erythrocytes and thrombocytes and (B) leukocytes.

\section{Discussion}

This study detected evidence of Bartonella spp. in domestic dogs and cats in Bangkok, Thailand. The results indicated that the prevalence of Bartonella in the total cat population 
evaluated was $2.53 \%$, however, Bartonella spp. was observed only in free-ranging cats. The current study found two species of Bartonella (B. henselae and B. clarridgeiae) which was similar with another study in Thailand that also reported that B. henselae and B. clarridgeiae as the main species in this region [17]. Evidence of Bartonella bacteremia was found in 13 cats, however, all dogs were negative to Bartonella in this study. In cats, this positive proportion contrasted with other Bartonella prevalence reported in Brazil [18,19], Greece [20], Italy [21,22], Germany [23], New Caledonia [24], USA [25-29], Saudi Arabia [30], Israel [31], Portugal [32], France [33,34], and Thailand [17], but was significantly similar with studies in Italy [35,36], Spain [37], Scotland [38], Ireland [39], and China [13]. Moreover, our study also demonstrated that the prevalence of Bartonella spp. in dogs was not significantly different from studies in China [13], Brazil [18], Spain [37], Cape Verde [40], and Grenada [41], but contrasted with other studies where Bartonella spp. were detected in cardiac tissues [42,43] and blood [42,44-46]. Importantly, there was a chance of an event that Bartonella was positive only in cardiac tissue but no evidence in blood [42]. Conversely, the detection in dogs in the current study was different from another study conducted in Thailand [46]. Additionally, dogs were defined as accidental hosts with some cardiac abnormalities [47] and cats were the major reservoir hosts presenting only subclinical disease or non-specific signs [48]. This explained why dogs were seldom detected as having Bartonella DNA in their blood samples. Comparisons of prevalence differences between recent and previous studies are presented in Supplementary Table S3. This different prevalence was affected from several different factors mainly including the detection technique, studied region, and host type. The geographic location and host type were considered as factors related to the prevalence of Bartonella [49]. Strayed animals frequently revealed a higher prevalence of Bartonella than owned animals [49] and these were caused by the difference of caring pattern, ectoparasite control, and ranging area. Thus, the negative prevalence in owned animals in this study was also caused by these aspects. Importantly, cyclic bacteremia of Bartonella was the main factor causing a false negative. For the detection method, sensitivity was the impacted factor that caused the different prevalence. Moreover, the concentration of Bartonella DNA might not match with the sensitivity of the test [47] and caused the different prevalence rate. The real-time and nested PCR presented a higher sensitivity than conventional PCR for Bartonella detection [13]. However, cPCR was less time and cost consumption than others. Additionally, various primers for cPCR had been completely produced compared to the real-time and nested PCR.

The prevalence of Bartonella spp. in the current study is quite low. The low prevalence in this study was suspected to be caused by direct pathogen detection from the bacteremia level in blood samples [44,50,51] and cyclic bacteremia characteristic of Bartonella spp. [52] at the sampling time. Additionally, some studies mentioned the lack of PCR sensitivity for Bartonella spp. detection in clinical samples, e.g., blood, other body fluids, and tissues [53]. Compared with the bacterial culture, PCR was suggested as a highly successful technique for Bartonella diagnosis in humans and experimental cats [54]. Although nested PCR was more sensitive than $\mathrm{CPCR}$, the available primers for CPCR that used to target Bartonella spp. were quite more abundant. Due to the phylogenetic study, the longest sequence product of CPCR was more useful than the nested PCR for analysis. Additionally, the Bartonella Alphaproteobacteria growth medium (BAPGM) pre-enrichment was suggested for the specimen culture in Bartonella spp. to increase the sensitivity rate of PCR detection compared with the direct DNA extraction from pure samples [46]. Even if BAPGM increased the PCR sensitivity, non-Bartonella spp. had been also co-isolated with Bartonella spp. especially environmental bacteria, non-pathogenic commensal organism, and skin normal flora [55,56], and contamination was considered.

Only free-ranging cats were found with Bartonella DNA. Additionally, some studies concluded that the prevalence of Bartonella infection in stray animals was higher than in pet animals [16,49]. However, the current study indicated no associated factor that was significantly related with Bartonella-positive animals. This was consistent with other studies that found no difference in prevalence based on gender, residing location, living 
pattern, age, and ectoparasitic appearance [21]. A contrasting result in Thailand reported that young cats and flea-infested cats were mostly found with Bartonella spp [17]. We found a high positive proportion in the inner zone of Bangkok where there are many residences on crown land. This area should be considered for the introduction of disease transmission protection against zoonotic diseases, especially bartonellosis.

Bartonella henselae and B. clarridgeiae were the major species detected in cats [16]. These species have been reported in various countries in Southeast Asia [57-60]. In previous reports, Thailand had endocarditis patients infected with B. henselae [61] and B. vinsonii subsp. arupensis [62]. Of these, there was evidence to support the impact of zoonotic Bartonella infection in Thailand. Bartonella henselae was reported as the main species causing zoonotic infection, especially via cat-scratch disease. In Southeast Asia, it has been suggested that $B$. henselae and $B$. clarridgeiae are the species affecting human health and of veterinary importance [63]. In the main, B. henselae and B. clarridgeiae are transmitted to humans via cat fleas (C. felis) [64] which are generally found on cats and dogs worldwide [65] and C. felis is the major vector as the pathogen-transmissible insect for feline bartonellosis [66].

The current study used primers targeting the gltA gene of Bartonella spp. for screening. Using glt $A$ detection, this gene had a high specificity for Bartonella detection in extracted DNA samples from blood [67]. The current BLAST results for the glt $A$ and ribC-amplified amplicons revealed a similar species of Bartonella. Additionally, other studies mentioned that positive Bartonella samples targeting the ribC gene were also positive to glt $A$ in all samples due to the higher detection power of glt $A$ [68-70]. However, there was no correlation for the BLAST results with the other housekeeping genes (rpoB, ftsZ, and groEL) in the current study. This might have been due to the low discriminatory power of some genes, except for $r p o B$, for species differentiation in the Bartonella genus [67]. On the other hand, the lack of correlated BLAST results might have been due to the co-infection of Bartonella spp. in individual cats. From the results, it was difficult to make any conclusions regarding the mixed infection at this time. Nevertheless, co-infection should be investigated using other more sensitive techniques.

Bartonella-positive free-ranging cats had raised values for MCV. Over 36\% of bacteremic cats had low values for HGB and MCHC. Another study in dogs mentioned that Bartonella-infected blood was significantly low in hemoglobin (HGB), erythrocytic mass (RBC), and hematocrit (HCT) [71]. The same trend was reported in a hematological study in camels, where the Bartonella-positive animals were significantly low in HGB, $\mathrm{MCH}$, and MCHC [72]. The mechanisms of anemia were studied mainly in B. bacilliformis and were described in various ways [73]. Bartonella-positive animals frequently showed anemia, eosinophilia, neutrophilia, and thrombocytopenia in [14,74]. Additionally, Bartonella-infected cats mostly showed mild or no abnormality of blood panels [18]. However, one hematological study in domestic cats revealed that MCV was noticeably low [75]. Interestingly, the hematological abnormalities caused by Bartonella spp. were rarely described in naturally infected cats presented as healthy carriers [11,76]. For significantly raised MCV values, we suggested that its volume was increased from two main ways: (1) From multiplied daughter cells of Bartonella in red blood cells in the replication stage [11], and (2) from another previous infection or immune-mediated disorder [28]. In addition, strong evidence suggested that heme compounds were necessary for $B$. henselae growth and hemoglobin was a potential source of heme in vivo [77] which explained the low values for HGB and MCHC in over $36 \%$ of Bartonella-positive cats in this study. Nevertheless, there are some limitations including the criteria for owned animals' inclusion. A significant inclusion criterion for blood donors of studied samples that might affect Bartonella detection in owned animals required an ectoparasite control. Flea- and tick-controlled animals were possibly a chance of negative Bartonella detection. Due to the ectoparasite infestation, there was a risk factor for Bartonella infection in dogs and cats [78]. However, Bartonella detection in ectoparasite was not included in this study. For further study, Bartonella spp. in animal-infesting ectoparasites should be examined to describe the dynamics of pathogen transmission. 


\section{Materials and Methods}

\subsection{Animal Ethics Consideration}

Blood samples were collected by veterinarians and involved the gentle restraint technique. This animal research study was approved by the Kasetsart University Institutional Animal Care and Use Committee under the Ethical Review Board of the Office of National Research Council of Thailand (NRCT). All the laboratories used in this study met the standards followed by verification of the Institutional Biosafety Committee (IBC), Faculty of Veterinary Medicine, Kasetsart University (approval ID ACKU63-VET-048).

\subsection{Definition of Surveyed Population}

In this study, we surveyed both free-ranging and owned animals. Free-ranging animals were dogs and cats residing in temples of Bangkok. These animals were fed by animal care takers of each temple. Moreover, the ectoparasite control history of free-ranging animals was unknown. Owned animals were dogs and cats registered at the Blood Bank (BB) unit of Kasetsart University Veterinary Teaching Hospital (KUVTH) for blood donors. Owned animals lived only in the household and they roamed only in the area around their houses. The criteria for blood donors at BB of KUVTH included a limited age (1-7 years), flea and tick continue control, no blood receive history, no drug usage, and required body weight (dogs $\geq 17 \mathrm{~kg}$ and cats $\geq 4 \mathrm{~kg}$ ).

\subsection{Study Sites and Sample Collection}

This cross-sectional study was conducted in the Bangkok metropolis of Thailand. The animal caretakers and owners of animals that resided in temples and registered with the BB at KUVTH, respectively were invited to participate in this study. Animal that had resided in temples were defined as free-ranging animals and animals that had donated blood at the BB of KUVTH were defined as owned animals. The temples that consented in this study were in three zones of Bangkok (Figure 1). Thirty-four districts were intervened, and the number of animals per temples were based on the difficulty of handling and density of animals in the area. The data of the studied population are presented in Supplementary Table S4. Blood samples from the free-ranging dogs were collected from the cephalic or saphenous vein depending on the size of the animal and in the donor dog samples were collected from the jugular vein. Additionally, cat samples consisted of punctured venous blood only from the jugular vein in both free-ranging and donor cats. Approximately $3 \mathrm{~mL}$ of blood was placed into a sterile blood collection tube with EDTA anticoagulant. Two hundred microliters of collected blood was separated for molecular detection of Bartonella spp. and the remaining volume was used for hematological evaluation.

\subsection{Animal's General Data Collection}

General data were collected for both free-ranging and owned animals including gender, living area, breed, age, and ectoparasite presentation at the surveyed time. Data of free-ranging animals were interviewed from the animal caretaker, however, data of owned animals were brought from the KUVTH record database and BB unit logbook. For ectoparasite presentation, they were examined at the time of blood collection and type of ectoparasite was recorded.

\subsection{Genomic DNA Extraction}

The separated blood samples were extracted for genomic DNA using commercial kits (FavorPrep ${ }^{\mathrm{TM}}$ Blood DNA Extraction Mini Kit, Favorgen Biotech Corporation, Pingtung, Taiwan) following the manufacturer's instructions. The final volume of eluted solution $(100 \mu \mathrm{L})$ was stored at $-20^{\circ} \mathrm{C}$ until the PCR-based detection. 


\subsection{PCR Quality Control}

Each PCR reaction was conducted with negative and positive control samples. Nucleasefree water was used as the Bartonella negative control. B. henselae Houston-1 extracted DNA was provided from the National Institute of Health, Department of Medical Science, Ministry of Public Health, Thailand and used as the positive control sample.

\subsection{Bartonella Screening Using PCR}

Conventional PCR was performed to detect Bartonella spp. in the extracted samples. First, all of the samples were screened for Bartonella spp. using a primer set targeting a partial fragment of the citrate synthase $(g l t A)$ gene (Table 5). The amplification conditions were controlled by a thermocycler (Mastercycler ${ }^{\circledR}$ nexus gradient, Eppendorf, Hamburg, Germany). The $25 \mu \mathrm{L}$ of PCR mixture contained $0.5 \mu \mathrm{L}$ of dNTPs solution $(0.2 \mathrm{mM}$ each), $1 \mathrm{X}$ of Taq Reaction buffer (mixed with $\mathrm{MgSO}_{4}$ ), $4 \mathrm{pmol} / \mu \mathrm{L}$ of each primer, $0.04 \mathrm{U} / \mu \mathrm{L}$ of Taq DNA polymerase (Taq DNA Polymerase, Applied Biological Materials $\left(\mathrm{ABM}^{\circledR}\right)$ Inc., Richmond, BC, Canada), $0.8 \%$ of dimethyl sulfoxide, and $3 \mu \mathrm{L}$ of DNA template. The amplified products were kept at $4{ }^{\circ} \mathrm{C}$ until electrophoresis. Electrophoresis was conducted using agarose gel under a $0.5 \mathrm{X}$ TAE buffer. The process of electrophoresis was run at $100 \mathrm{~V}$ for 40-60 min depending on the expected amplicon size. The sample bands which were suspected as being positive for the Bartonella amplicon size were purified using a DNA purification kit (Gel and PCR Purification System, BioFACT ${ }^{\mathrm{TM}}$, Daejeon, South Korea), according to the manufacturer's instructions.

Table 5. Primer list used for Bartonella detection in this study.

\begin{tabular}{|c|c|c|c|c|c|}
\hline Primer Name & Gene & Direction & Primer Sequence & Amplicon Size (bp) & Reference \\
\hline BhCS.781p & glt $A$ & Forward & GGGGACCAGCTCATGGTGG & 379 & [68] \\
\hline BhCS.1137n & & Reverse & AATGCAAAAAGAACAGTAAACA & & \\
\hline $1400 \mathrm{~F}$ & rров & Forward & CGCATTGGCTTACTTCGTATG & 795 & [79] \\
\hline $1400 \mathrm{~F}$ & & Reverse & GTAGACTGATTAGAACGCTG & & \\
\hline BaftsZF & ftsZ & Forward & GCTAATCGTATTCGCGAAGAA & 885 & [80] \\
\hline BaftsZR & & Reverse & GCTGGTATTTCCAAYTGATCT & & \\
\hline HSPF1d & groEL & Forward & GAACTNGAAGATAAGTTNGAA & 1188 & [81] \\
\hline BbHS1630.n & & Reverse & AATCCATTCCGCCCATTC & & \\
\hline BARTON-1 & $\mathrm{ribC}$ & Forward & TAACCGATATTGGTTGTGTTGAAG & 540 & [69] \\
\hline BARTON-2 & & Reverse & TAAAGCTAGAAAGTCTGGCAACATAACC & & \\
\hline
\end{tabular}

bp: Base pair.

\subsection{Other Housekeeping Gene Amplification}

The Bartonella-suspected samples were amplified for other housekeeping gene fragments (Table 5) consisting of the beta-subunit of RNA polymerase (rpoB), cell division protein (ftsZ), $60 \mathrm{kDa}$ chaperonin ( $g r o E L)$, and riboflavin synthase (ribC). The amplification cycles for each housekeeping gene are shown in Table 6. Additionally, the PCR mixture, amplified amplicon, gel electrophoresis, and DNA purification were used as for the above description of $g l t A$.

Table 6. Polymerase chain reaction conditions of each housekeeping gene for Bartonella detection.

\begin{tabular}{|c|c|c|c|c|c|c|}
\hline Gene & Initial Denaturation & Denaturation & Annealing & Extension & Final Extension & Repeated Cycle \\
\hline glt $A$ & $95^{\circ} \mathrm{C}(5 \mathrm{~m})$ & $95^{\circ} \mathrm{C}(20 \mathrm{~s})$ & $51{ }^{\circ} \mathrm{C}(30 \mathrm{~s})$ & $72{ }^{\circ} \mathrm{C}(2 \mathrm{~m})$ & $72{ }^{\circ} \mathrm{C}(5 \mathrm{~m})$ & 35 \\
\hline rpoB & $94^{\circ} \mathrm{C}(2 \mathrm{~m})$ & $94^{\circ} \mathrm{C}(30 \mathrm{~s})$ & $53{ }^{\circ} \mathrm{C}(30 \mathrm{~s})$ & $72{ }^{\circ} \mathrm{C}(1 \mathrm{~m})$ & $72^{\circ} \mathrm{C}(2 \mathrm{~m})$ & 35 \\
\hline ftsZ & $94^{\circ} \mathrm{C}(4 \mathrm{~m})$ & $94^{\circ} \mathrm{C}(30 \mathrm{~s})$ & $55{ }^{\circ} \mathrm{C}(30 \mathrm{~s})$ & $68^{\circ} \mathrm{C}(1 \mathrm{~m})$ & $68^{\circ} \mathrm{C}(10 \mathrm{~m})$ & 44 \\
\hline groEL & $94^{\circ} \mathrm{C}(3 \mathrm{~m})$ & $94^{\circ} \mathrm{C}(30 \mathrm{~s})$ & $54{ }^{\circ} \mathrm{C}(30 \mathrm{~s})$ & $72{ }^{\circ} \mathrm{C}(1.5 \mathrm{~m})$ & $72{ }^{\circ} \mathrm{C}(7 \mathrm{~m})$ & 40 \\
\hline ribC & $95^{\circ} \mathrm{C}(10 \mathrm{~m})$ & $95^{\circ} \mathrm{C}(1 \mathrm{~m})$ & $51^{\circ} \mathrm{C}(1 \mathrm{~m})$ & $72{ }^{\circ} \mathrm{C}(1 \mathrm{~m})$ & $72^{\circ} \mathrm{C}(3 \mathrm{~m})$ & 37 \\
\hline
\end{tabular}




\subsection{DNA Sequencing and Phylogenetic Analyses}

The purified amplicons were analyzed using Sanger's sequencing technology by a commercial company (Macrogen ${ }^{\circledR}$, Seoul, Korea). The obtained DNA sequences were edited using the SnapGene ${ }^{\circledR}$ Viewer software version 5.2.4 (https:/ / www.snapgene.com/ snapgene-viewer, accessed on 20 March 2021) and the phylogenetic relationship was analyzed using the MEGA-X software (https:/ / www.megasoftware.net, accessed on 20 March 2021). Concatenated sequences were used to establish a phylogenetic tree under the fitted parameter model of the maximum likelihood method with 500 bootstrapping replications. All amplicon sequences were submitted to GenBank (accession numbers MW575344-MW575394).

\subsection{Hematological Analyses}

The remaining blood samples were sent to the Hematological Unit of KUVTH and to a private hematological company. All of the blood samples were analyzed using the laser flow cytometry technique by an automated hematology analyzer (Sysmex XT-2000iV ${ }^{\mathrm{TM}}$, IDEXX Bioresearch, Norderstedt, Germany). Additionally, a manual differential count from the Diff-Quick stained blood smear was also performed in all of the samples. Common blood panels were analyzed based on the leukocyte count (WBC) and the proportions of neutrophils (NEU), lymphocytes (LYM), eosinophils (EOS), monocytes (MON), and by the numbers of basophils (BAS), the erythrocytic count (RBC), hemoglobin concentration (HGB), packed cell volume (PCV), mean corpuscular volume (MCV), mean corpuscular hemoglobin $(\mathrm{MCH})$, mean corpuscular hemoglobin concentration $(\mathrm{MCHC})$, and platelet count (PLT).

\subsection{Statistical Analyses}

General data on the tested animals were recorded for age, sex, breed, roaming/living location, ectoparasitic infestation, and living pattern. The general and hematological data were statistically analyzed using the $\mathrm{R}$ programming language version 4.0.2. Variables of interest were tested as risk factors using Chi square or Fisher's exact test depending on the nature of the recorded data. Only the significant factors were analyzed, and a multiple comparison used the Bonferroni correction method and calculated odds ratio. A comparison of hematological values was tested between Bartonella-positive and Bartonellanegative groups using the Mann-Whitney $U$ test. All statistical analyses were processed using $95 \%$ confidence intervals and a $p$-value $<0.05$ was considered as significant.

\section{Conclusions}

Overall, the prevalence of Bartonella spp. in domestic animals in Bangkok, Thailand was $1.61 \%$ and was only identified in free-ranging cats $(2.83 \%)$. There was no evidence of Bartonella in domestic dogs. Two zoonotic species were identified in this study (B. henselae and B. clarridgeiae). There was a high proportion detected in temple clusters located in the inner zone of Bangkok, however, there were no significant differences for other associated factors. The $100 \%$ bootstrapping replication of the concatenated phylogenetic tree based on the $g l t A$ and $r i b C$ genes confirmed the two species of Bartonella spp. in this study. Nevertheless, other genes ( $r p o B$, ftsZ, and groEL) revealed different species from the same individual sample and mixed infection was expected. Bartonella-positive, free-ranging cats had raised MCV values compared to negative cats, additionally, there were low values of HGB and MCHC in over $36 \%$ of the Bartonella-positive cats. Based on these results, we suggest that zoonotic Bartonella spp., especially B. henselae and B. clarridgeiae, are important in Thailand and a prevention program, such as routine health checks of animals and humans, should be implemented. Importantly, abnormal red blood cell parameters such as a high corpuscular volume or low hemoglobin-related parameters in healthy cats should also be considered as indicators of feline subclinical bartonellosis in Thailand. Moreover, the knowledge of Bartonella-related diseases protection should be intervened in the risk person. 
Supplementary Materials: The following are available online at https:/ / www.mdpi.com/article/10 .3390 / pathogens10050503/s1. Table S1: Details of sequencing data obtained in this study and their related-BLAST; Table S2: The reference of blood parameters used for cut-off in this study; Table S3: Comparison of positive and negative-Bartonella proportions between a recent investigation and other reports discussed in this study; Table S4: The data of studied population in this study.

Author Contributions: Conceptualization, T.I. and G.K.; methodology, P.S.; software, P.S.; validation, P.S., T.I., and G.K.; data acquisition, P.S., T.I., and G.K.; data curation, P.S. and T.I.; writing-original draft preparation, P.S.; writing—review and editing, T.I. and G.K.; supervision, T.I. and G.K.; funding acquisition, T.I. All authors have read and agreed to the published version of the manuscript.

Funding: This research is supported by the Center of Excellence on Agricultural Biotechnology, Science and Technology Postgraduate Education and Research Development Office, Office of Higher Education Commission, Ministry of Higher Education, Science, Research and Innovation. (AG$\mathrm{BIO} / \mathrm{PERDO}-\mathrm{CHE})$ grant number AG-BIO/61-003-011.

Institutional Review Board Statement: Not applicable.

Informed Consent Statement: Not applicable.

Data Availability Statement: Data is contained within the article and supplementary materials.

Acknowledgments: The authors thank all staff and the undergraduate and graduate students of the Department of Parasitology, Faculty of Veterinary Medicine, Kasetsart University, Bangkok, Thailand who helped during the sample collection. Decha Pangjai, specialist medical scientist at The National Institute of Health, Department of Medical Science, Ministry of Public Health, Thailand provided the extracted DNA of Bartonella henselae strain Houston 1 that was used as the positive control in this study.

Conflicts of Interest: The authors declare that they have no conflicting or competing financial or personal interests that could influence the work reported in this study.

\section{References}

1. Bouhsira, E.; Ferrandez, Y.; Liu, M.; Franc, M.; Boulouis, H.-J.; Biville, F. Ctenocephalides felis an in vitro potential vector for five Bartonella species. Comp. Immunol. Microbiol. Infect. Dis. 2013, 36, 105-111. [CrossRef]

2. Brouqui, P.; Raoult, D. Arthropod-borne diseases in homeless. Ann. N. Y. Acad. Sci. 2006, 1078, 223-235. [CrossRef]

3. Ulutasdemir, N.; Eroglu, F.; Tanrıverdi, M.; Dagli, E.I.; Koltas, I.S. The epidemic typhus and trench fever are risk for public health due to increased migration in southeast of Turkey. Acta Trop. 2018, 178, 115-118. [CrossRef]

4. Battisti, J.M.; Lawyer, P.G.; Minnick, M.F. Colonization of Lutzomyia verrucarum and Lutzomyia longipalpis sand flies (Diptera: Psychodidae) by Bartonella bacilliformis, the etiologic agent of Carrión's disease. PLoS Negl. Trop. Dis. 2015, 9, e0004128. [CrossRef]

5. Wechtaisong, W.; Bonnet, S.I.; Lien, Y.-Y.; Chuang, S.-T.; Tsai, Y.-L. Transmission of Bartonella henselae within Rhipicephalus sanguineus: Data on the potential vector role of the tick. PLoS Negl. Trop. Dis. 2020, 14, e0008664. [CrossRef]

6. Sréter-Lancz, Z.; Tornyai, K.; Széll, Z.; Sréter, T.; Márialigeti, K. Bartonella infections in fleas (Siphonaptera: Pulicidae) and lack of bartonellae in ticks (Acari: Ixodidae) from Hungary. Folia Parasitol. 2006, 53, 313-316. [CrossRef]

7. Dwużnik, D.; Mierzejewska, E.J.; Drabik, P.; Kloch, A.; Alsarraf, M.; Behnke, J.M.; Bajer, A. The role of juvenile Dermacentor reticulatus ticks as vectors of microorganisms and the problem of "meal contamination". Exp. Appl. Acarol. 2019, 78, 181-202. [CrossRef] [PubMed]

8. Prutsky, G.; Domecq, J.P.; Mori, L.; Bebko, S.; Matzumura, M.; Sabouni, A.; Shahrour, A.; Erwin, P.J.; Boyce, T.G.; Montori, V.M.; et al. Treatment outcomes of human bartonellosis: A systematic review and meta-analysis. Int. J. Infect. Dis. 2013, 17, e811-e819. [CrossRef]

9. Guptill, L. Bartonellosis. Vet. Microbiol. 2010, 140, 347-359. [CrossRef] [PubMed]

10. Boulouis, H.-J.; Chang, C.-C.; Henn, J.B.; Kasten, R.W.; Chomel, B.B. Factors associated with the rapid emergence of zoonotic Bartonella infections. Vet. Res. 2005, 36, 383-410. [CrossRef]

11. Deng, H.; Pang, Q.; Zhao, B.; Vayssier-Taussat, M. Molecular mechanisms of Bartonella and mammalian erythrocyte interactions: A review. Front. Cell. Infect. Microbiol. 2018, 8, 431. [CrossRef] [PubMed]

12. Yuan, C.; Zhu, C.; Wu, Y.; Pan, X.; Hua, X. Bacteriological and molecular identification of Bartonella species in cats from different regions of China. PLoS Negl. Trop. Dis. 2011, 5, e1301. [CrossRef]

13. Zhang, X.-L.; Li, X.-W.; Li, W.-F.; Huang, S.-J.; Shao, J.-W. Molecular detection and characterization of Bartonella spp. in pet cats and dogs in Shenzhen, China. Acta Trop. 2019, 197, 105056. [CrossRef]

14. Álvarez-Fernández, A.; Breitschwerdt, E.B.; Solano-Gallego, L. Bartonella infections in cats and dogs including zoonotic aspects. Parasit. Vectors 2018, 11, 624. [CrossRef]

15. Chomel, B.B.; Kasten, R.W. Bartonellosis, an increasingly recognized zoonosis. J. Appl. Microbiol. 2010, 109, 743-750. [CrossRef] 
16. Chomel, B.B.; Boulouis, H.-J.; Maruyama, S.; Breitschwerdt, E.B. Bartonella spp. in pets and effect on human health. Emerg. Infect. Dis. 2006, 12, 389-394. [CrossRef]

17. Assarasakorn, S.; Veir, J.K.; Hawley, J.R.; Brewer, M.M.; Morris, A.K.; Hill, A.E.; Lappin, M.R. Prevalence of Bartonella species, hemoplasmas, and Rickettsia felis DNA in blood and fleas of cats in Bangkok, Thailand. Res. Vet. Sci. 2012, 93, $1213-1216$. [CrossRef]

18. Da Silva, B.T.G.; de Souza, A.M.; Campos, S.D.E.; Macieira, D.d.B.; de Lemos, E.R.S.; Favacho, A.R.d.M.; Almosny, N.R.P. Bartonella henselae and Bartonella clarridgeiae infection, hematological changes and associated factors in domestic cats and dogs from an Atlantic rain forest area, Brazil. Acta Trop. 2019, 193, 163-168. [CrossRef] [PubMed]

19. André, M.R.; Baccarim Denardi, N.C.; Marques de Sousa, K.C.; Gonçalves, L.R.; Henrique, P.C.; Grosse Rossi Ontivero, C.R.; Lima Gonzalez, I.H.; Cabral Nery, C.V.; Fernandes Chagas, C.R.; Monticelli, C.; et al. Arthropod-borne pathogens circulating in free-roaming domestic cats in a zoo environment in Brazil. Ticks Tick Borne Dis. 2014, 5, 545-551. [CrossRef]

20. Mylonakis, M.E.; Schreeg, M.; Chatzis, M.K.; Pearce, J.; Marr, H.S.; Saridomichelakis, M.N.; Birkenheuer, A.J. Molecular detection of vector-borne pathogens in Greek cats. Ticks Tick Borne Dis. 2018, 9, 171-175. [CrossRef] [PubMed]

21. Pennisi, M.G.; La Camera, E.; Giacobbe, L.; Orlandella, B.M.; Lentini, V.; Zummo, S.; Fera, M.T. Molecular detection of Bartonella henselae and Bartonella clarridgeiae in clinical samples of pet cats from Southern Italy. Res. Vet. Sci. 2010, 88, 379-384. [CrossRef] [PubMed]

22. Ebani, V.V.; Bertelloni, F.; Fratini, F. Occurrence of Bartonella henselae types I and II in Central Italian domestic cats. Res. Vet. Sci. 2012, 93, 63-66. [CrossRef]

23. Mietze, A.; Morick, D.; Köhler, H.; Harrus, S.; Dehio, C.; Nolte, I.; Goethe, R. Combined MLST and AFLP typing of Bartonella henselae isolated from cats reveals new sequence types and suggests clonal evolution. Vet. Microbiol. 2011, 148, 238-245. [CrossRef] [PubMed]

24. Mediannikov, O.; Davoust, B.; Cabre, O.; Rolain, J.-M.; Raoult, D. Bartonellae in animals and vectors in New Caledonia. Comp. Immunol. Microbiol. Infect. Dis. 2011, 34, 497-501. [CrossRef] [PubMed]

25. Kelly, P.J.; Moura, L.; Miller, T.; Thurk, J.; Perreault, N.; Weil, A.; Maggio, R.; Lucas, H.; Breitschwerdt, E. Feline immunodeficiency virus, feline leukemia virus and Bartonella species in stray cats on St Kitts, West Indies. J. Feline Med. Surg. 2010, 12, 447-450. [CrossRef]

26. Dowers, K.L.; Hawley, J.R.; Brewer, M.M.; Morris, A.K.; Radecki, S.V.; Lappin, M.R. Association of Bartonella species, feline calicivirus, and feline herpesvirus 1 infection with gingivostomatitis in cats. J. Feline Med. Surg. 2010, 12, 314-321. [CrossRef]

27. Powell, C.C.; McInnis, C.L.; Fontenelle, J.P.; Lappin, M.R. Bartonella species, feline herpesvirus-1, and Toxoplasma gondii PCR assay results from blood and aqueous humor samples from 104 cats with naturally occurring endogenous uveitis. J. Feline Med. Surg. 2010, 12, 923-928. [CrossRef]

28. Ishak, A.M.; Radecki, S.; Lappin, M.R. Prevalence of Mycoplasma haemofelis, 'Candidatus Mycoplasma haemominutum', Bartonella species, Ehrlichia species, and Anaplasma phagocytophilum DNA in the blood of cats with anemia. J. Feline Med. Surg. 2007, 9, 1-7. [CrossRef]

29. Lappin, M.R.; Griffin, B.; Brunt, J.; Riley, A.; Burney, D.; Hawley, J.; Brewer, M.M.; Jensen, W.A. Prevalence of Bartonella species, haemoplasma species, Ehrlichia species, Anaplasma phagocytophilum, and Neorickettsia risticii DNA in the blood of cats and their fleas in the United States. J. Feline Med. Surg. 2006, 8, 85-90. [CrossRef]

30. Alanazi, A.D.; Alouffi, A.S.; Alyousif, M.S.; Alshahrani, M.Y.; Abdullah, H.H.A.M.; Abdel-Shafy, S.; Calvani, N.E.; Ansari-Lari, M.; Sazmand, A.; Otranto, D. Molecular survey of vector-borne pathogens of dogs and cats in two regions of Saudi Arabia. Pathogens 2021, 10, 25. [CrossRef]

31. Lappin, M.R.; Breitschwerdt, E.; Brewer, M.; Hawley, J.; Hegarty, B.; Radecki, S. Prevalence of Bartonella species antibodies and Bartonella species DNA in the blood of cats with and without fever. J. Feline Med. Surg. 2009, 11, 141-148. [CrossRef] [PubMed]

32. Alves, A.S.; Milhano, N.; Santos-Silva, M.; Santos, A.S.; Vilhena, M.; de Sousa, R. Evidence of Bartonella spp., Rickettsia spp. and Anaplasma phagocytophilum in domestic, shelter and stray cat blood and fleas, Portugal. Microbiol. Infect. Dis. 2009, 15 (Suppl. 2), 1-3. [CrossRef]

33. La Scola, B.; Davoust, B.; Boni, M.; Raoult, D. Lack of correlation between Bartonella DNA detection within fleas, serological results, and results of blood culture in a Bartonella-infected stray cat population. Clin. Microbiol. Infect. 2002, 8, 345-351. [CrossRef] [PubMed]

34. Gurfield, A.N.; Boulouis, H.-J.; Chomel, B.B.; Kasten, R.W.; Heller, R.; Bouillin, C.; Gandoin, C.; Thibault, D.; Chang, C.-C.; Barrat, F.; et al. Epidemiology of Bartonella infection in domestic cats in France. Vet. Microbiol. 2001, 80, 185-198. [CrossRef]

35. Otranto, D.; Napoli, E.; Latrofa, M.S.; Annoscia, G.; Tarallo, V.D.; Greco, G.; Lorusso, E.; Gulotta, L.; Falsone, L.; Basano, F.S.; et al. Feline and canine leishmaniosis and other vector-borne diseases in the Aeolian Islands: Pathogen and vector circulation in a confined environment. Vet. Parasitol. 2017, 236, 144-151. [CrossRef] [PubMed]

36. Zobba, R.; Chessa, G.; Mastrandrea, S.; Parpaglia, M.L.P.; Patta, C.; Masala, G. Serological and molecular detection of Bartonella spp. in humans, cats and dogs from northern Sardinia, Italy. Clin. Microbiol. Infect. 2009, 15, 134-135. [CrossRef]

37. Millán, J.; Proboste, T.; Fernández de Mera, I.G.; Chirife, A.D.; de la Fuente, J.; Altet, L. Molecular detection of vector-borne pathogens in wild and domestic carnivores and their ticks at the human-wildlife interface. Ticks Tick Borne Dis. 2016, 7, 284-290. [CrossRef] 
38. Bennett, A.D.; Gunn-Moore, D.A.; Brewer, M.; Lappin, M.R. Prevalence of Bartonella species, haemoplasmas and Toxoplasma gondii in cats in Scotland. J. Feline Med. Surg. 2011, 13, 553-557. [CrossRef]

39. Juvet, F.; Lappin, M.R.; Brennan, S.; Mooney, C.T. Prevalence of selected infectious agents in cats in Ireland. J. Feline Med. Surg. 2010, 12, 476-482. [CrossRef]

40. Lauzi, S.; Maia, J.P.; Epis, S.; Marcos, R.; Pereira, C.; Luzzago, C.; Santos, M.; Puente-Payo, P.; Giordano, A.; Pajoro, M.; et al. Molecular detection of Anaplasma platys, Ehrlichia canis, Hepatozoon canis and Rickettsia monacensis in dogs from Maio Island of Cape Verde archipelago. Ticks Tick Borne Dis. 2016, 7, 964-969. [CrossRef]

41. Yabsley, M.J.; McKibben, J.; Macpherson, C.N.; Cattan, P.F.; Cherry, N.A.; Hegarty, B.C.; Breitschwerdt, E.B.; O’Connor, T.; Chandrashekar, R.; Paterson, T.; et al. Prevalence of Ehrlichia canis, Anaplasma platys, Babesia canis vogeli, Hepatozoon canis, Bartonella vinsonii berkhoffii, and Rickettsia spp. in dogs from Grenada. Vet. Parasitol. 2008, 151, 279-285. [CrossRef]

42. Roura, X.; Santamarina, G.; Tabar, M.-D.; Francino, O.; Altet, L. Polymerase chain reaction detection of Bartonella spp. in dogs from Spain with blood culture-negative infectious endocarditis. J. Vet. Cardiol. 2018, 20, 267-275. [CrossRef] [PubMed]

43. Davis, A.Z.; Jaffe, D.A.; Honadel, T.E.; Lapsley, W.D.; Wilber-Raymond, J.L.; Kasten, R.W.; Chomel, B.B. Prevalence of Bartonella sp. in United States military working dogs with infectious endocarditis: A retrospective case-control study. J. Vet. Cardiol. 2020, 27, 1-9. [CrossRef]

44. Yore, K.; DiGangi, B.; Brewer, M.; Balakrishnan, N.; Breitschwerdt, E.B.; Lappin, M. Flea species infesting dogs in Florida and Bartonella spp. prevalence rates. Vet. Parasitol. 2014, 199, 225-229. [CrossRef]

45. Singer, G.A.; Loya, F.P.; Lapsley, W.D.; Tobar, B.Z.; Carlos, S.; Carlos, R.S.; Carlos, E.T.; Adao, D.E.V.; Rivera, W.L.; Jaffe, D.A.; et al. Detection of Bartonella infection in pet dogs from Manila, the Philippines. Acta Trop. 2020, 205, 105277. [CrossRef]

46. Bai, Y.; Kosoy, M.Y.; Boonmar, S.; Sawatwong, P.; Sangmaneedet, S.; Peruski, L.F. Enrichment culture and molecular identification of diverse Bartonella species in stray dogs. Vet. Microbiol. 2010, 146, 314-319. [CrossRef]

47. Fontalvo, M.C.; Favacho, A.R.d.M.; Araujo, A.d.C.; Dos Santos, N.M.; de Oliveira, G.M.B.; Aguiar, D.M.; de Lemos, E.R.S.; Horta, M.C. Bartonella species pathogenic for humans infect pets, free-ranging wild mammals and their ectoparasites in the Caatinga biome, Northeastern Brazil: A serological and molecular study. Braz. J. Infect. Dis. 2017, 21, 290-296. [CrossRef]

48. Maia, C.; Ramos, C.; Coimbra, M.; Bastos, F.; Martins, Â.; Pinto, P.; Nunes, M.; Vieira, M.L.; Cardoso, L.; Campino, L. Bacterial and protozoal agents of feline vector-borne diseases in domestic and stray cats from southern Portugal. Parasit. Vectors 2014, 7 , 115. [CrossRef]

49. Rolain, J.-M.; Locatelli, C.; Chabanne, L.; Davoust, B.; Raoult, D. Prevalence of Bartonella clarridgeiae and Bartonella henselae in domestic cats from France and detection of the organisms in erythrocytes by immunofluorescence. Clin. Diagn. Lab. Immunol. 2004, 11, 423-425. [CrossRef]

50. Rubio, A.V.; Ávila-Flores, R.; Osikowicz, L.M.; Bai, Y.; Suzán, G.; Kosoy, M.Y. Prevalence and genetic diversity of Bartonella strains in rodents from northwestern Mexico. Vector Borne Zoonotic Dis. 2014, 14, 838-845. [CrossRef] [PubMed]

51. André, M.R.; Dumler, J.S.; Herrera, H.M.; Gonçalves, L.R.; de Sousa, K.C.M.; Scorpio, D.G.; de Santis, A.C.G.A.; Domingos, I.H.; de Macedo, G.C.; Machado, R.Z. Assessment of a quantitative 5' nuclease real-time polymerase chain reaction using the nicotinamide adenine dinucleotide dehydrogenase gamma subunit (nuoG) for Bartonella species in domiciled and stray cats in Brazil. J. Feline Med. Surg. 2015, 18, 783-790. [CrossRef] [PubMed]

52. Harms, A.; Dehio, C. Intruders below the radar: Molecular pathogenesis of Bartonella spp. Clin. Microbiol. Rev. 2012, 25, 42-78. [CrossRef] [PubMed]

53. Oteo, J.A.; Maggi, R.; Portillo, A.; Bradley, J.; García-Álvarez, L.; San-Martín, M.; Roura, X.; Breitschwerdt, E. Prevalence of Bartonella spp. by culture, PCR and serology, in veterinary personnel from Spain. Parasit. Vectors 2017, 10, 553. [CrossRef] [PubMed]

54. Roy, A.F.; Corstvet, R.E.; Tapp, R.A.; Oreilly, K.L.; Cox, H.U. Evaluation and use of a nested polymerase chain reaction assay in cats experimentally infected with Bartonella henselae genotype I and Bartonella henselae genotype II. J. Vet. Diagn. Investig. 2001, 13, 312-322. [CrossRef]

55. Davenport, A.C.; Mascarelli, P.E.; Maggi, R.G.; Breitschwerdt, E.B. Phylogenetic diversity of bacteria isolated from sick dogs using the BAPGM enrichment culture platform. J. Vet. Intern. Med. 2013, 27, 854-861. [CrossRef]

56. Cadenas, M.B.; Maggi, R.G.; Diniz, P.P.V.P.; Breitschwerdt, K.T.; Sontakke, S.; Breithschwerdt, E.B. Identification of bacteria from clinical samples using Bartonella alpha-Proteobacteria growth medium. J. Microbiol. Methods 2007, 71, 147-155. [CrossRef]

57. Chomel, B.B.; Carlos, E.T.; Kasten, R.W.; Yamamoto, K.; Chang, C.C.; Carlos, R.S.; Abenes, M.V.; Pajares, C.M. Bartonella henselae and Bartonella clarridgeiae infection in domestic cats from The Philippines. Am. J. Trop. Med. Hyg. 1999, 60, 593-597. [CrossRef]

58. Marston, E.L.; Finkel, B.; Regnery, R.L.; Winoto, I.L.; Graham, R.R.; Wignal, S.; Simanjuntak, G.; Olson, J.G. Prevalence of Bartonella henselae and Bartonella clarridgeiae in an urban Indonesian cat population. Clin. Diagn. Lab. Immunol. 1999, 6, 41-44. [CrossRef]

59. Maruyama, S.; Sakai, T.; Morita, Y.; Tanaka, S.; Kabeya, H.; Boonmar, S.; Poapolathep, A.; Chalarmchaikit, T.; Chang, C.C.; Kasten, R.W.; et al. Prevalence of Bartonella species and 16s rRNA gene types of Bartonella henselae from domestic cats in Thailand. Am. J. Trop. Med. Hyg. 2001, 65, 783-787. [CrossRef]

60. Mokhtar, A.S.; Tay, S.T. Molecular detection of Rickettsia felis, Bartonella henselae, and B. clarridgeiae in fleas from domestic dogs and cats in Malaysia. Am. J. Trop. Med. Hyg. 2011, 85, 931-933. [CrossRef]

61. Watt, G.; Pachirat, O.; Baggett, H.C.; Maloney, S.A.; Lulitanond, V.; Raoult, D.; Bhengsri, S.; Thamthitiwat, S.; Paupairoj, A.; Kosoy, M.; et al. Infective endocarditis in northeastern Thailand. Emerg. Infect. Dis. 2014, 20, 473-476. [CrossRef] [PubMed] 
62. Bai, Y.; Kosoy, M.Y.; Diaz, M.H.; Winchell, J.; Baggett, H.; Maloney, S.A.; Boonmar, S.; Bhengsri, S.; Sawatwong, P.; Peruski, L.F. Bartonella vinsonii subsp. arupensis in humans, Thailand. Emerg. Infect. Dis. 2012, 18, 989-991. [CrossRef] [PubMed]

63. Nguyen, V.-L.; Dantas-Torres, F.; Otranto, D. Canine and feline vector-borne diseases of zoonotic concern in Southeast Asia. Curr. Res. Parasitol. Vector-Borne Dis. 2021, 1, 100001. [CrossRef]

64. Bitam, I.; Dittmar, K.; Parola, P.; Whiting, M.F.; Raoult, D. Fleas and flea-borne diseases. Int. J. Infect. Dis. 2010, 14, e667-e676. [CrossRef]

65. Lawrence, A.L.; Webb, C.E.; Clark, N.J.; Halajian, A.; Mihalca, A.D.; Miret, J.; D’Amico, G.; Brown, G.; Kumsa, B.; Modrý, D.; et al. Out-of-Africa, human-mediated dispersal of the common cat flea, Ctenocephalides felis: The hitchhiker's guide to world domination. Int. J. Parasitol. 2019, 49, 321-336. [CrossRef]

66. Foil, L.; Andress, E.; Freeland, R.L.; Roy, A.F.; Rutledge, R.; Triche, P.C.; O'Reilly, K.L. Experimental infection of domestic cats with Bartonella henselae by inoculation of Ctenocephalides felis (Siphonaptera: Pulicidae) feces. J. Med. Entomol. 1998, 35, 625-628. [CrossRef]

67. La Scola, B.; Zeaiter, Z.; Khamis, A.; Raoult, D. Gene-sequence-based criteria for species definition in bacteriology: The Bartonella paradigm. Trends Microbiol. 2003, 11, 318-321. [CrossRef]

68. Norman, A.F.; Regnery, R.; Jameson, P.; Greene, C.; Krause, D.C. Differentiation of Bartonella-like isolates at the species level by PCR-restriction fragment length polymorphism in the citrate synthase gene. J. Clin. Microbiol. 1995, 33, 1797-1803. [CrossRef]

69. Johnson, G.; Ayers, M.; McClure, S.C.C.; Richardson, S.E.; Tellier, R. Detection and identification of Bartonella species pathogenic for humans by PCR amplification targeting the riboflavin synthase gene (ribC). J. Clin. Microbiol. 2003, 41, 1069-1072. [CrossRef]

70. Buffet, J.-P.; Kosoy, M.; Vayssier-Taussat, M. Natural history of Bartonella-infecting rodents in light of new knowledge on genomics, diversity and evolution. Future Microbiol. 2013, 8, 1117-1128. [CrossRef]

71. Samsami, S.; Ghaemi, M.; Sharifiyazdi, H. Molecular detection and phylogenetic analysis of 'Candidatus Bartonella merieuxii' in dogs and its effect on hematologic parameters. Comp. Immunol. Microbiol. Infect. Dis. 2020, 72, 101504. [CrossRef]

72. Ghaemi, M.; Sharifiyazdi, H.; Heidari, F.; Nazifi, S.; Ghane, M. "Candidatus Bartonella dromedarii" in the dromedary camels of Iran: Molecular investigation, phylogenetic analysis, hematological findings, and acute-phase proteins quantitation. Vet. Microbiol. 2019, 237, 108404. [CrossRef] [PubMed]

73. Hendrix, L.R. Contact-dependent hemolytic activity distinct from deforming activity of Bartonella bacilliformis. FEMS Microbiol. Lett. 2000, 182, 119-124. [CrossRef] [PubMed]

74. Souza, A.M.; Almosny, N.R.P.; Favacho, A.R.M.; Almeida, D.N.P.; Ferreira, R.F.; Ferreira, E.O.; Moreira, N.S.; Lemos, E.R.S. Bartonella spp. and hematological changes in privately owned domestic cats from Rio de Janeiro, Brazil. J. Infect. Dev. Ctries. 2017, 11, 591-596. [CrossRef] [PubMed]

75. Müller, A.; Walker, R.; Bittencourt, P.; Machado, R.Z.; Benevenute, J.L.; DO Amaral, R.B.; Gonçalves, L.R.; André, M.R. Prevalence, hematological findings and genetic diversity of Bartonella spp. in domestic cats from Valdivia, Southern Chile. Parasitology 2017, 144, 773-782. [CrossRef] [PubMed]

76. Chomel, B.B.; Boulouis, H.-J.; Breitschwerdt, E.B.; Kasten, R.W.; Vayssier-Taussat, M.; Birtles, R.J.; Koehler, J.E.; Dehio, C. Ecological fitness and strategies of adaptation of Bartonella species to their hosts and vectors. Vet. Res. 2009, 40, 29. [CrossRef]

77. Sander, A.; Kretzer, S.; Bredt, W.; Oberle, K.; Bereswill, S. Hemin-dependent growth and hemin binding of Bartonella henselae. FEMS Microbiol. Lett. 2000, 189, 55-59. [CrossRef]

78. Beugnet, F.; Halos, L. Parasitoses E Vector Borne Diseases of Cats; Merial: Lyon, France, 2015.

79. Renesto, P.; Gouvernet, J.; Drancourt, M.; Roux, V.; Raoult, D. Use of rpoB gene analysis for detection and identification of Bartonella species. J. Clin. Microbiol. 2001, 39, 430-437. [CrossRef] [PubMed]

80. Zeaiter, Z.; Liang, Z.; Raoult, D. Genetic classification and differentiation of Bartonella species based on comparison of partial ftsZ gene sequences. J. Clin. Microbiol. 2002, 40, 3641-3647. [CrossRef]

81. Zeaiter, Z.; Fournier, P.-E.; Ogata, H.; Raoult, D. Phylogenetic classification of Bartonella species by comparing groEL sequences. Int. J. Syst. Evol. Microbiol. 2002, 52, 165-171. [CrossRef] [PubMed] 